\title{
EFFECTIVE LEADERSHIP AND CHANGE IN EdUCATION: How CAN HEAD TEACHERS CONTRIBUTE IN ENHANCING THE OUTCOMES OF STUDENTS WITH SPECIAL NEEDS IN MAINSTREAM SCHOOLS?
}

\author{
BY \\ AmaAl Almigal \\ LECTURER - FACULTY OF EDUCATION \\ SHAQRA UNIVERSITY - SAUDI ARABIA \\ PHD CANDIDATE \\ UNIVERSITY COLLEGE OF LONDON \\ DOI : 10.12816/0052741

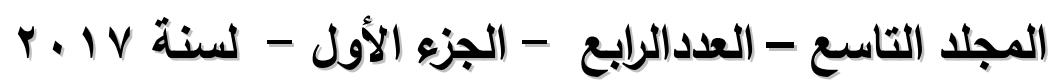

مجلة الدراسات التريوية والانسانية ـ كلية التربية ـ جامعة دمنهور . 
EFFECTIVE LEADERSHIP AND CHANGE IN EDUCATION: How Can Head Teachers Contribute in Enhancing THE OUTCOMES OF STUDENTS WiTH SPECIAL NEEDS IN MAINSTREAM SCHOOLS?

AMAAL ALMIGAL

DOI : 10.12816/0052741

\begin{abstract}
This paper argued that inclusion is a main challenge that educational institutions around the world may face. The focus is on the role of head teachers in creating and developing an environment that responds positively to inclusion. Reflecting on evidence from research and literature on the factors that head teachers should consider in promoting the standards of their schools and, therefore, the level of knowledge and skills of students with and without special education needs (SEN) in mainstream schools. These factors will be discussed within the elements inside schools (leaders, staff and students) and collaboration between schools and elements that lie outside the school context (parents and caregiver, other mainstream and special schools). As a consequence of these discussions, some of the barriers that head teachers may encounter when working on these factors will be addressed in the third section and this will be accompanied with a discussion of the advantages that are likely to be gained as a result of these leadership behaviours.
\end{abstract}

\title{
Key words:
}

leadership, head teacher, principal, students, teachers, special needs, inclusion, disabilities, outcome 


\section{Introduction}

Inclusive education has been the focus of copious research that considers the development of policy and practice (Dyson, Gallannaugh, $\&$ Millward, 2002). To meet the requirement of successful inclusion, schools need qualified educators who are eager to continue their learning and respond positively to changes in their contexts to meet the needs of all learners Forbes (2007). Forbes also emphasises that inclusive systems require highly skilled leaders whose knowledge provides for different needs.

Riehl (2002) argues the role of leaders in challenging the inclusive context can be summarized by work in three different areas: developing new meanings of diversity related to equity, social justice, and voice, encouraging inclusive practices in their contexts, and building bridges between schools and community by creating positive connections linking different elements with positive influence on inclusive settings. In Ainscow's (1999) point of view, schools with inclusive working approaches are more likely to move toward successful inclusion. This stresses transformational leadership that distributes and empowers individuals rather than transactional leadership's traditional model of control, domination, and hierarchy (Sergiovanni, 1992).

This paper will discuss the role of head teachers in implementing leadership to improve the standards of their schools and the outcomes of their students, focusing on the inclusion of students with special education needs (SEN). The first section will demonstrate head teachers' responsibilities in increasing the effectiveness of elements within schools. The second part will argue the importance of working co-operatively and collegially with external factors at individual and institutional levels. The last section will reflect on research evidence in the field of inclusive education so that implications can be drawn for individuals who play the leadership role in their contexts.

DOI $10.12816 / 0052741$ 


\section{Section One: Internal elements that head teachers could improve}

Leaders of inclusive schools should seek to create collaborative institutional culture. Kugelmass (2001) indicates collaboration could empower both students and teachers; teachers may become able to sustain collaborative settings as a consequence of support from their principals. Collaboration not only enriches individual teaching but also supports the students' learning inside and outside the classrooms. This section will argue for the importance of improving individuals within the school to improve the outcomes of students with SEN.

1.1Head teachers (themselves)

Education leaders who seek further education in practices that support the learning of individuals in their settings demonstrate the strong connection between leadership and learning (Swaffield \& MacBeath, 2009). A recent report by Day et al. (2009) reveals that the impact of leadership on students' outcomes emphasises the significance of leadership in improving the learning of educators as well as students.

Effective schools possess elements connected to leadership and management (Smith, 1995). Head teachers should understand the importance of the sustainability of their roles. Sindelar et al. (2006) argue that leadership change is one of the most significant factors influencing the sustainability of innovations in inclusive schools. This can be attributed to the commitment that educators may acquire as they develop of innovations.

Moreover, schools that retain principals are more likely to be able to sustain classroom strategies than those where principals are rotated occasionally. Head teachers' commitment to specific agendas can play a vital role in sustaining or driving new reforms (Sindelar et al., 2006). Therefore, if the principal of an inclusive school has changed, this might impact the whole school's context unless the new principal has the same or higher commitment as the first. Consequently, inclusion can be affected by principals and their championing of new plans. However, an inclusive context needs collaboration; it is inadequate to rely on the commitment of only some teachers; more teamwork is needed when collaborating to solve problems (Ingram, 1997). A collegial style of leadership can increase the level of enthusiasm of followers as they become more empowered through decision making (Stoll \& Myers, 1998).

As school culture can influence a schools' inclusion, school leaders should have the ability to manage this culture (Harris, 1992). Hunt and Goetz (1997) investigated nineteen studies on the development of 
successful inclusion and the components of high performance in school culture, but they did not find any research that directly connects schools' cultures and successful inclusion. However, later, Zollers, Ramanathan and $\mathrm{Yu}$ (1999) identify inclusive leadership as one of the most significant elements contributing to the success of inclusive settings, as it assists leaders in protecting schools from negative influences. This can be attributed to the values that inspired leaders to adopt the idea of building an open climate of values, respecting support for diversity using democratic methods, and value-driven leadership styles.

Moreover, Lambert (2002) argues for shared leadership that involves teachers and students in constructing common meaning that aims at shared purposes. As a consequence, the role of principals is to lead a group of leaders replacing hierarchical approaches by shared hopes, visions, and values. Blackmore (1999) and Ryan (2006a) emphasize that leadership in inclusive schools should seek for moral aims like social justice. They believe schools, as part of the community, should aim to achieve fairness for everyone. Ryan (2006b) attributes concerns about social justice to the noticeable diversity in today's schools.

However, inclusive schools' leaders should understand the interaction between top-down and bottom-up approaches of leadership in to facilitate the process of change as they could act as change facilitators, helping shape visions and providing resources to implement new plans. When leaders use bottom-up leadership, staff can increase their skills as they become actively engaged in change process; this can also create deeper collegiality, improving staff satisfaction about their work (Villa $\&$ Thousand, 2005).

\subsection{Teachers}

New teachers, especially those who work with SEN students, are more likely to be isolated at work (Billingslley, Carlson, \& Klein, 2004). To boost their sense of belonging, they should be supported emotionally by leaders through different strategies. For instance, support might be expressed in a welcoming reception by leaders. Those leaders could encourage other staff to make new teachers feel connected. Furthermore, leaders should listen to new teachers to show they are available to support them. Induction programs can help new teachers understand that responsibilities are shared. Leaders need to comment positively on new teachers' performance, and to identify areas in which they need support by involving new teachers in peer meetings where they are more likely to share their concerns with others. However, if

DOI $10.12816 / 0052741$ 
leaders offer too much support, new teachers may become less confident about their performance (Billingsley, 2005).

Other staff may also need support. The way teachers feel and act toward including students with SEN in their classes might be one of the most important factors of inclusive education; their attitude has effects inside the classroom and influences the options they choose in educating their students (Atta, Shah, \& Khan, 2002). This attitude can be influenced by the principals' values and beliefs; they could inspire the teachers' behaviours to be stronger (Avramidis \& Norwich, 2002). A study by Stanovich and Jordan (1998) provides evidence that teachers' attitudes and the school's ethos may impact teachers'behaviour towards inclusion.

Research collecting data from both teachers and students, using methods including surveys, conversations, observations, and videotaping, shows teachers need professional development experiences to improve their general education; some teachers do not believe they have adequate preparation to meet either the behavioural or academic needs of their students (Schumm \& Vaughn, 1992; McIntosh et al., 1993; Schumm et al., 1994). Vaughn and Schumm (1995) assert teachers should be equipped with professional development using traditional approaches (for instance, mini-courses or university coursework) and innovative options such as visiting each other's classes or having professional monitor teachers' practices. This development should be periodically reviewed and reformed.

Principals should express their interest in research-based practices and teachers' learning to establish school cultures that support collaborative professional learning. Head teachers should also foster the use of this learning in new practices and assist teachers to adopt new innovations by providing them with time, resources, and feedback (Billingsley, 2005). Bennis and Nanus (1985) claim that transformational leadership allows subordinates a degree of competence essential to reach the institutions aims. This should inspire individuals to see they can achieve higher levels with greater personal effort (Bass \& Avolio, 1990).

Head teachers should encourage teachers to utilize innovations in their practices, as innovations are important in inclusive schools' development. They provide students with the latest tools and strategies to support their learning. The leader-teachers' role is crucial in innovating contexts. They should be supported by enforcers who understand the implementation of innovation and the significance of its continuous usage. Advancement opportunities for those using innovation could motivate teachers (Huberman \& Miles, 1984). 
However, as change is required to develop innovations, head teachers should be engaged in the change process. The human mind needs stability (Schein, 1992). Carrington and Robinson (2004) emphasise that change can be accompanied by anxiety and stress, so inclusive schools leaders should create a climate of collaboration in change procedures by involving themselves and their staff. In this democratic planning practice, leaders may become more likely to form inclusive schools as collaborative learning environment. Similarly, shared leadership between principals and teachers can change schools through communication about each role's expectations. A culture of dialogue is essential to an inclusive school context; this culture is less likely in present organisations (Rice, 2006). It may require fostering healthy working relationships.

Considerable research on the influence of leadership on schools' improvement stresses the significance of social relationships (Hopkins, Ainscow, \& West, 1994). Leaders could construct working relationships between staff in one of three forms. In the first, competitive approach, teachers work against each other toward accomplishing a purpose not all of them can reach. The second involves teachers working individually to achieve goals that are not related to other teachers' goals. In the third approach, teachers follow cooperative procedures by collaborating toward achieving the same goals. Leaders may need to challenge existing traditional individualistic and competitive strategies by inspiring teacher mutual visions for collaboration; becoming an example by working co-operatively with them; and encouraging them to build on their experience to become more expert in their professions (Johnson \& Johnson, 1989).

SENCOs (Special Education Needs Co-ordinators) also have important influences on students' outcomes. The values of head teachers could have direct influence on the practices of SENCOs in fostering inclusive culture; without the head teachers' support, facing the challenge of diversity may be more difficult (Cole, 2005). Head teachers should ensure SENCOs have adequate development and training.

As staff and their skills and functions vary, it is important to recognise individuals who could be involved in taking action. As Villa and Thousand (2005) claim, some individuals prefer to understand "big picture" of change by discussing issues before beginning the process, while others are more enthusiastic to establish new plans for action to move quickly towards development. By discussing the issues involved in any changes, the individuals involved can be encouraged to apply

DOI $10.12816 / 0052741$ 
action in their roles and relationships and contribute in structuring successful organisations.

\subsection{Students}

Head teachers should support students to broaden their strategies of learning not only by implementing different teaching approaches but also by trusting their experiences. Booth, Nes and Stromstad, 2003 highlight that shared experience and group-based language can reduce the amount of time used to teach students some literacy skills. This could provide teachers with a higher level of critical thinking in practicing discussion about their experience.

Conversation can be a turning point to success. Collecting the visions of all learners could provide them with the sense of belonging and also enable them to be more independent. Its importance lies in its consideration for students' social, emotional, and effective progress (Villa \& Thousand, 2005). Principals' support for students should involve making sure that all students receive the assistance they are entitled to so their outcomes could increase (Forbes, 2007). To provide for the needs of students "at the margins" head teachers need to direct their schools towards a higher level of capacity, meeting these needs using a variety of learning approaches that rely on different levels of abilities (Sergiovanni, 1994).

A large body of research proves there is a strong connection between the students' self-esteem and their outcomes and students with SEN are more likely to experience lower self-esteem than their classmates (Lawrence, 1987). Key individuals in the students' setting could have a negative impact on the SEN students' self-esteem by actions that affect the students' feelings. By contrast, leaders can improve students' selfesteem by giving them the chance to contribute to decisions taken for changes in their schools by listening to their views, including them in the process of learning, and supporting them with skills that assist their learning. Consequently, enabling students to contribute in their schools' life could impact positively on their achievements as they become more likely to have higher self-esteem (Jelly, Fuller, \& Byers, 2000).

Some research showed that using instructional leadership in schools can be a key element that contributes to the students' outcomes (Hallinger \& Heck, 1998; Guskey, 2003). Therefore, head teachers should frequently use data collection about students' achievement when taking decisions in order to be more proficient in implementing instructional leadership; by sharing these decisions a plan can be drawn to improve the students' performance (Sanzo, Clayton, \& Sherman, 2011). These decisions can 
involve the instruction of their schools, professional development, and the process used to implement changes (O'Donnell \& White, 2005).

To summarise this section, it would appear that, to develop professional learning communities, a school's culture seems to be one of the main issues that should be considered by school leaders to apply successful change. Both Ainscow (1999) and Fullan (2002) emphasise that leadership is a main element to achieve this, particularly transformational leadership. Fullan (2002) expresses that head teachers should be responsible for creating a culture of collaboration in their schools. The author identifies these aspects to be worked on: providing resources, material support and a climate of trust; building on expertise; dealing with difficulties and the complexity of their context; celebrating success; considering empowerment, assertiveness, and accountability. Further, distributive leadership also be one of the main elements to manage successful changes beside collaboration, vision creation, and accountability (Attfield \& Williams, 2003).

Section Two: External elements that head teachers could work with

School leaders should involve both family members and community members as essential parts in the construction of their schools' improvement (Dettmer, Thurston, \& Dyck, 1993). Stakes and Hornby (2000) justify the significance of school-home partnership for students with SEN as their parents need more assistance and guidance to meet the needs of their children. School leaders should develop a statement of beliefs for the students with SEN and this statement should be generated from communication with not only staff and students but also the parents and community (Porter, 1997).

2.1Parents

It is the positive effect of involving parents in the education process that leads some of the makers of relevant policy and legislation (such as the "No Child Left Behind Act'") to judge this involvement as a main component when considering the improvement of students' academic and behaviour achievements (Epstein, 2005). There is a positive relationship between parent involvement and students' academic outcomes (Sheldon and Epstein, 2005; Fan, 2001). Therefore, parents should be encouraged to work collaboratively with educators in taking decisions about the students' learning (Trainor, 2010). Garcia, Perez and Ortiz (2000) describe their participation as a valuable way by which the efficacy of educating students with SEN can be increased.

Will (1986) emphasises establishing school-parents' programs to create home environments that support their academic goals. This can increase the supervision of home-works, foster conversations between parents

DOI $10.12816 / 0052741$ rAT 
and their children, increase the amount of reading, and decrease watching non-beneficial television programmes. Therefore, the outcomes of students can improve.

Parents need leaders and teachers to be available to respond to their requirements and to support them emotionally as well as educationally. They need to be provided with information about their children's progress and the services provided for their children's needs in language they can understand (Lacey, 2003). Parents of students with SEN should be provided with professional advice and resources that could assist them in supporting for their children (Pijl, Meijer, \& Hegarty, 1997). Leaders should encourage teachers to be in contact with parents (Ryan, 2003). Davis (1995) emphasise that parents should be informed about their children's progress and not only given negative feedback.

There are a variety of communication approaches that can be used to connect schools with families of students with SEN either formally or informally. These include written communication, phone contact, parent-teacher meetings, and home visits. However, there are certain skills that leaders and teachers should consider to insure fruitful parentschool communication, such as listening, consulting, and assertion skills (Stakes \& Hornby, 2000). Some principals emphasise that they need to be the starting point in this relationship, as some families may not participate unless there is an indication for them to do so (Ryan, 2003).

Todd (2007) clarifies the family involvement in different ways that include learning and support, involvement in their children's assessment, and participating in voluntary work. Lacey (2003) argues that organizations should review and reform their process to respond to the parents' concerns but some leaders express a degree of difficulty in establishing this relationship in a diverse community.

Head teachers should make an effort to persuade families who do not participate and should encourage them to meet their children's teachers. They should also facilitate eliminating any barriers that parents might face and might lead them to step back from participation; for instance, some Asian parents may not participate because of language difficulties. Although most schools' leaders value the partnership with parents and positive relationships in their context, some of them express that it is crucial to establish relationships with other organizations in their communities (Ryan, 2003). 


\subsection{Other organizations}

Not only should teachers be encouraged to continue their learning, they also need to be supported by critical friends who can reflect on their practices. Carrington and Robinson (2004) explain the concept of a "critical friend" as someone outside of the school's context who can be trusted to provide teachers with valuable feedback about their performance. For instance, a primary school teacher can occasionally meet a university lecturer in inclusive education as a critical friend. This can be applied with researchers or teachers' group meetings. Billingsley (2005) clarifies that by contacting universities, leaders could find a resource of specialists in special education. Visiting faculties of special needs schools could help leaders to provide their staff with knowledge about special needs by attending classes in universities.

Moreover, head teachers should establish positive relationships with other schools. Collaboration across schools could help provide for the students with SEN learning. Their teachers could acquire benefits as a result of cooperation; by exchanging ideas they could become more confident and skilled to perform effectively in their inclusive classrooms (Pijl, Meijer, \& Hegarty, 1997).

One task that head teachers should consider is embedding their schools within the community. The effective leader is able to foster interorganisational work to benefit from other institutions' positive resources that might support their inclusive practices. This can be achieved if principals consider social justice, equity, and voice by creating an inclusive culture where the external relationships are positively built to support their settings (Riehl, 2000). By this practice, not only the students' needs can be met, but also the community where they live can be strengthened (Englert, 1993).

One way of implementing cooperation is when head teachers work with leaders from special education. Ainscow (2001) emphasises that those leaders should be given real attention as they play a vital role with respect to the development of mainstream schools. Attfield and Williams (2003) claim that special schools' leaders usually have unique skills that enable them to understand and provide for a variety of needs. These skills could assist in designing learning process and creating sustainable networks. They also are more likely to experience working with different groups of staff so that they become able to deal with the complexity of change.

However, co-operation between leaders is not adequate to transmit experiences into the classroom. Therefore, leaders should transfer this

$$
\text { DOI 10.12816/0052741 }
$$


collaboration to their staff. Atta, Shah and Khan (2002) highlight this as a strategy to create inclusive educators who are able to face the challenge of diversity within their classrooms. The authors explain that teachers should be equipped with general education strategies as well as special education approaches so they become more flexible and comfortable with the changes inclusive settings require.

Nevertheless, some educators find it difficult to transfer from one model to another. Providing them with experiences which assist them to be more creative can help them acquire knowledge and become more skilled in solving problems and seeing their contexts from different perspectives. This might include, for instance, knowledge about understanding students with SEN such as identifying their learning barriers and generating methods to create an environment that accommodates these barriers without negative impacts on other learners. It can be summarised that working with other organizations may require coordinators from each institution and shared physical space as well as team-work that aims to achieve parents' requirements for their children (Lacey, 2003).

To achieve successful change in inclusive practice, leaders, teachers, parents, and communities need to work together (Ryan, 2003). At this point, it can be concluded that although head teachers of inclusive schools should perform the roles of cheerleader, facilitator, emotional supporter, and coach in inclusive learning processes, staff, parents, outside communities, teachers, and students should have their voice in the process of changes occurring in their setting so that it is essentially collaborative work.

\section{Section Three: Implications for Practice}

Leadership for inclusion should be collective so that school leaders include individuals in the process of leadership, but they still need to contribute as they have the power from knowledge and experience to influence followers positively (Ryan, 2003). Although, as argued previously, the role of leaders is significant in inclusive practice (Theoharis \& Causton-Theoharis, 2008), it is not adequate to just understand its importance because many principals do not have enough knowledge to face the challenge of diversity (Sirotnik \& Kimball, 1994; Capper, Frattura, \& Keyes, 2000). Currently, there is a tendency to focus on educators' skill improvement and knowledge acquisition and competencies. However, personal professional development might be still missing (Davies \& Lee, 2001). This kind of development could 
provide practitioners with models of reflection on their personal and professional practices.

Leading for social justice has been the focus for a large body of research (Marshall \& Olivia, 2006). However, there is little literature that focuses on strategies to prepare head teachers to develop and lead inclusive schools effectively (Theoharis \& Causton-Theoharis, 2008). Theoharis and Causton-Theoharis (2008) suggest that using skilled educators and expertise in preparing inclusive schools' leaders can be beneficial to build on their knowledge towards creating and maintaining an inclusive environment. To adapt effective inclusive leadership, head teachers can be supported by showing them the negative impact of marginalization of teaching on the outcomes of students.

Although there is a small body of research in the impact of leadership on inclusive practice, there is a lot that can be learned about leadership for diversity. Achieving successful inclusion requires shared group work rather than relying on individual practices. Therefore, school leaders should involve individuals to contribute to their school's success (Ryan, 2003).

Though inclusive leadership can be a helpful strategy to achieve social justice in schools, and therefore in communities, implementing this approach can be challenging (Ryan, 2006b). This can be attributed to many possible difficulties, one of which is the managing strategies that are already embedded hierarchies (Blackmore, 1999; Gewirtz, 2002). Another barrier is that policies may place the responsibilities on one person such as the school's administrators (Ryan, 2006b). Anderson (1990) draws attention to the fact that the effort toward empower might be seen cynically and cultures that believe in heroes can also be an obstacle. In spite of all of these barriers Ryan (2006b) emphasises the importance of facing all of these challenges to create an inclusive leadership practice that seeks fairness for humanity.

Inclusive leadership should also include learning and teaching as a key element towards success, as all individuals, leaders, teachers, students, and parents may know little about inclusive practices. Therefore, leaders need to support all contributors by finding opportunities that serve different needs (Ryan, 2003).

With regard to teachers, a study conducted by Rizzo (1984) reveals that teachers may have negative views towards the inclusion of students with disabilities. A large number of teachers showed their preference to place students in special classes even though their disabilities were mild (Knoff, 1984). Leaders' behaviour could have an impact on teachers' attitudes, and therefore influences students' achievement. This attitude

DOI 10.12816/0052741

หヘT 
may have positive or negative effects on the students' achievement (Foster, Ysseldyke, \& Reese, 1975). Furthermore, leaders' behaviour could have a great impact on the success of change and innovations implemented in their practices (Bowers, 1999). Therefore, Ingram (1997) assumes that it should also influence the teachers' attitude towards accepting and implementing inclusion. Principals should influence the teachers' motivations by their leadership behaviour (Bass, 1985), because if there is an absence of motivations and commitment, teachers may not perform their best in practice (Sergiovanni, 1991).

Since leadership approaches should be considered by schools' principals, Ingram (1997) argues that transformational leadership seems to have higher influence on teachers' attitudes than transactional leadership. As Blase (1990) concludes, the latter has no or little impact on teachers' attitudes.

It can be argued that transformational leadership may influence inclusive context in different ways. Ryan (2003) states that despite the fact that transformational leadership can help leaders in diverse settings; some of its aspects might not be useful or sometimes dangerous. A study by Ingram (1997) reveals that leaders of inclusive schools are seen as transformational leaders more than transactional, as they are more likely to share values, goals, and decisions with their teams more than transactional leaders who are less likely to create a collaborative work environment. This can lead teachers to focus their effort on their individual classes. However, Clough (1998) suggests that it is not necessary that collaborative leadership be transformational, as the former can result from a co-operative style (Busher \& Saran, 1995), or from any type of collegiality (Hargreaves, 1994).

On one hand, transactional leadership can assist leaders in increasing the subordinates' awareness of the significance of sharing aims (Burns, 1978). It shares components with other approaches of leadership. For example, it has similar aspects to the charismatic approach (Bass \& Aviolo, 1994), and in the relationship between leaders and followers, it can be similar to humanistic and managerial leadership (Ryan, 2003).

On the other hand, some characteristics of transformational leadership can have negative influences in an inclusive context. For instance, it may allow individuals to take actions which can be risky. Just as some qualified individuals can positively influence the context, weak individuals might have negative impacts on the practice. Another implication is involving parents in taking decisions. It is argued that despite the fact that transformational leaders work towards involving individuals in their decisions, the actions taken may just reflect what the 
transformational leaders believe is significant, although it might be not the best decision from the followers' perspectives (Ryan, 2003).

As far as collegiality is concerned, principals should create positive relationships in their context depending on trust, openness and respect for others (Billingsley, 2005). By increasing the level of co-operation between staff and participants, they can share knowledge with others, which may result in improving the whole organisation (Carrington \& Robinson, 2004). However, with regard to leadership, some current government policies show leadership in a structure of missions and behaviours that can be seen as a contrast to the calls for collegiality between schools and co-operation that seeks for responses to the students' needs (Rayner, Gunter, \& Powers, 2002).

Collegiality should be implemented between all staff members. To support the idea that improved students' outcomes cannot be achieved unless the behaviour of adults in their contexts changes, school leaders should create a climate of collaboration that starts from building on the capacity of staff to think of the achievements that could be reached as a result of their group-work, and raises their sense of responsibility toward reaching their aims. This might also include solving problems that are related to the outcomes, attendance, and behaviour of certain students (Ainscow, 2005).

However, Elmore, Peterson, and McCarthy (1996) draw attention to the fact that some barriers need to be solved individually before they are organisationally. Lipman (1997) emphasises a similar idea, indicating that some evidence shows increasing collegiality could have a negative impact on the teachers' practices as they might reinforce the existing strategies as a result of the marginalisation of making changes in the individual level.

As professional development is a significant factor in improving any learning environment, it can be a priority in an inclusive context where there is a diversity of learning needs. To meet the requirement of these differing needs, Carrington and Robinson (2004) indicate that professional development should be considered not only at the individual level where the teachers' skills should be enhanced, but also at the whole school level by analysing and revising the beliefs and values of individuals about the schools' policies and practices, such as teaching approaches. This could facilitate forming shared visions that are an aspect of the school's culture. However, although teachers are encouraged to use a variety of teaching strategies, it is sometimes difficult for them to practice new approaches as the environment in their

DOI $10.12816 / 0052741$ 
classrooms might not always be organized to assist its implementation (Hawley \& Valli, 1999).

Implementing effective inclusion will likely involve increased financial expenditures (McLaughlin \& Warren, 1993). To provide for responsible, inclusive school personnel and physical resources should be considered, for instance, additional teachers, teacher assistants (TAs), SENCOs, computers and books (Zollers, Ramanathan and Yu, 1999). Sufficient resources should be provided to meet the needs of all students and the quality of these resources is the matter of concern not the quality (Billingsley, 2005). However, interviews with some teachers suggest that the lack of adequate resources in their contexts creates some difficulties in achieve successful inclusion (Vaughn et al., 1996).

As far as students are concerned, it can be argued that although that it is crucial to listen to the students when applying changes in inclusive practice, it is likely that a challenging climate can be created for school leaders, who might need to use different styles of leadership which develop their ability to challenge diversity to generate more ideas for improvement (Ainscow \& Kaplan, 2006).

Furthermore, Sammons, Hillman and Mortimore (1995) highlight that having an active role for the students in actions taken towards change in their school lives can create more opportunities for them to gain higher self-esteem. For example, by making them engaged in the observation of their own learning process to achieve specific difficulties, or supporting them by leaders and teachers and listening to their voice, leaders could subsidise the improvement and development of their schools and, therefore, their learning (Fullan, 1992). However, Jelly, Fuller and Byers (2000) argue that it is not adequate to identify the students' views and visions to a particular phenomenon; there is a need to transfer these visions into actions that could contribute positively in their context.

Nevertheless, listening to the students' voice could have an impact on their classrooms' environment as well as the whole school context. For example, the partnership between students and their educators (Sarriere \& Mitra, 2012). Battistich and Horn (1997) add that it could also provide the students with a sense of identity as they become more likely to establish positive relationships as a result of having opportunities to talk in their class meetings. Basu (2008) also highlights the importance of "consultation" or listening to the students in enhancing their learning as they become more likely to acquire positive feeling about their abilities. Ainscow and Kaplan (2006) assert taking the views of students into account can be "a powerful lever of change" in inclusive schools.

r^9 
However, evidence collected from students' perspectives can be challenging. To address challenges that generate from this, principals could rely on different styles of leadership to meet the needs that emerge from a particular challenging situation.

With regard to school-family partnerships, although policy-makers call for involving parents in the education process, greater contact between professionals and parents may become the groundwork for programmes run for these families, as compassion for their conditions may influence the professionals' choices (Crockett \& Kauffman, 1999). One of the main barriers that leaders might encounter in making shared decisions with parents is that communication between parents and educators may become biased as they have different levels of access to significant capital resources. This may lead head teachers to diminish the empowerment of families as a consequence of the complexity that results from the interaction of backgrounds, races, ethics, languages, and experiences (Trainor, 2010).

However, educators should take advantage of the parents' anxious desire to improve their children. If educators and families set great expectations and celebrate any progress the student might make, plan together towards the students' success and appreciate them the way they are, this is more likely to motivate their parents to work collaboratively with schools to achieve successful inclusion for their children (Turnbull \& Turnbull, 2001).

Park and Turnbull (2001) argue that parents could also provide educators with knowledge that might help to face the challenge of cultural diversity. However, some families may agree to the professionals' opinions even if they might have different ideas. They might believe that their recommendation is trusted because they think the professionals know more than themselves. This might occur even if parents have completely different opinions, which may lead them to fail to implement the interventions recommended by the professionals. This could have a negative impact on the procedure of their children's learning. Another important issue in this regard was raised by Martin, Tett, and Kay (1999). They stated that even if head teachers commit to strengthening the school-home partnership, achieving their aims may require political support and resources.

Regarding organisational collaboration, students in both mainstream school and special institutions could benefit from the collaborative work between special and general schools. Educators and expertise from each school can work together to improve their practices (Attfield \& Williams, 2003). However, some head teachers indicate they do not

$$
\text { DOI } 10.12816 / 0052741
$$


have adequate preparation for interagency collaboration (Foley \& Lewis, 1999). Furthermore, although some organisations clearly state the significance of using collaborative work in their legislations, some individuals may not have inclination or time to perform this in practice (Lacey, 2003).

It seems that inclusive schools need inclusive leaders. It can be argued that all approaches of leadership may not be equally equipped to be perfectly implemented in inclusive contexts. For example, managerial, technical, humanistic and transformational leadership can serve inclusive practices at different levels using a variety of strategies (Ryan, 2003, p. 58).

It might be better to see inclusive leadership as process rather than a combination of skills and activities (Pajak \& Evans, 2000). This process need to be "educative" to assist individuals in learning what is not clear for them. Moreover, inclusive leadership is "reflective", so that leaders need to be critical and reflect on their practices. By engaging others in these reflections, great benefit can be acquired to improve their practices. For example, it could help teachers generate strategies that might support students with SEN. Further, as inclusive leadership involves practice, it is "transformative" as it can involve changes in both individuals and social settings, "equitable" so that all individuals in the context can be involved in its process. "Dialogical" and "nonhierarchical" could be other descriptions for inclusive leadership, as it includes a degree of involvement of all elements dialogically in its process (Ryan, 2003, p. 188).

Although the role of leaders in inclusive education has been conducted for decades, in some countries the development of this role is still in the foundation levels. The leaders' positive opinions about inclusion could act as motivation for the development of the students' learning in various aspects (Alkashrami, 2003). Similarly, Sartawi et al. (1988) studied the views of head teachers and staff in Riyadh and conclude that their level of knowledge and experience in the field of special needs has great impact on their views toward inclusion. The study reveals there is a tendency toward the acceptance of students with moderate disabilities. However, the vast majority still believe that other alternatives should be found for students with severe disabilities. Alabdaljabbar and Massoud (2001) attribute the variation in their opinions to their level of education, kind of job, the students' type of disabilities, and the kind of inclusive program. Deng and Holdsworth (2007) report that to achieve progress in inclusive schools, head teachers need to be provided with training and resources that support the performance of their roles efficiently. 


\section{Conclusion}

This paper explores the role of leaders in considering students with SEN by analysing the head teachers' practices towards successful inclusion of this category of students. It seems the leaders needed for inclusive practices are those who take their decisions using evidence from their setting as well as outside practices (Forbes, 2007), using different forms of leadership (Leo \& Barton, 2006).

Cordell and Waters (1993) categorise school systems as belonging to three "domains". The first is personal, where internal connections, environment and culture, supervision, and leadership are main components. The second is organizational, and includes the external environment. The third is technical, where standards, instructions, curriculum, and assessment are the main contributors. McRel (2000) describes these domains as different "lenses" that schools can be seen through. This paper considers the personal and organizational domains. However, the technical domain lies outside the scope of this paper.

It would appear, as this paper argued, that successful inclusion is less likely to be connected with individual elements, for instance, the amount of assistance provided for students. This evidence came from eighteen studies which suggest that interaction between different factors can create a climate that is ideal for promoting the students' learning (Ainscow, 2001). However, research is needed to clarify and direct the training needed for inclusive schools' leaders and to conduct deeply strategies to improve schools' practices and policies to be more inclusive. Further, leadership skills need to be addressed and improved to foster inclusive schools' development.

(6,386 words) 


\section{References}

\section{General books}

1)Ainscow, M. (1999) Understanding the Development of Inclusive Schools. London: Routledge Falmer.

2)Bass, B. and Aviolo, B. (1994) Improving Organizational Effectiveness through Transformational Leadership. Thousand Oaks: Sage.

3)Bass, B.M. (1985) Leadership and Performance Beyond Expectations. New York: The Free Press.

4)Bass, B.M. and Avolio, B.J. (1990) Transformational Leadership Development, Manual for the Multifactor Leadership Questionnaire. Palo Alto: Consulting Psychologist Press.

5)Bennis, W. and Nanus, B. (1985) Leaders: The Strategies for Taking Charge. NewYork: Harper and Row.

6)Billingsley, B.S. (2005) Cultivating and Keeping Committed Special Education Teachers: What Principals and District Leaders Can Do. California: Corwin Press.

7)Blackmore, J. (1999) Troubling Women. Buckingham: Open University Press.

8)Booth, T., Nes, K. and Stromstad, M. (2003) Developing Inclusive Teacher Education. London: Routledge Falmer.

9)Burns, J.M. (1978) Leadership. New York: Harper and Row.

10)Busher, H. and Saran, R. (Eds)(1995) Managing Teachers as Professionals in Schools. London: Kogan Page.

11)Capper, C.A., Frattura, E. and Keyes, M.A. (2000) Meeting the Need of Student of All Abilities: How Leaders go Beyond Inclusion. Thousand Oaks: Corwin.

12)Clough, P. (1998) Managing Inclusive Education: From Policy to Experience. London: Paul Chapman.

13)Cordell, F. and Waters, J.T. (1993) Improving Student Performance: New Strategies for Implementing Higher Standards. Greeley: The Center for Peak Performing Schools.

14)Crockett, J.B. and Kauffman, J.M. (1999) The Least Restrictive Environment: Its Origins and Interpretations in Special Education. Mahwah: Erlbaum.

15)Davis, B. (1995) How to Involve Parent in a Multicultural School. Alexandria: Association for Supervision and Curriculum Development. 
16)Dettmer, P., Thurston, L.P. and Dyck, N. (1993) Consultation, Collaboration, and Teamwork for Students with Special Needs. Boston: Allyn and Bacon.

17)Elmore, R.F., Peterson, P.L. and McCarthy, S.J. (1996) Restructuring in the Classroom: Teaching, Learning and School Organisation. San Francisco: Jossey-Bass.

18)Englert, R.M. (1993) Understanding the Urban Context and Conditions of Practice of School Administration. In: Forsyth, P.B. and Tallerico, M. (Eds.) City schools: Leading the way. Newbury Park: Corwin Press.

19)Fullan, M. (1992) What's Worth Fighting in Headship?. Buckingham: Open University Press.

20)Fullan, M. (2002) Leading in a Culture of Change. London: Leannta Education Associations.

21)Gewirtz, S. (2002) The managerial school: Post-welfarism and social justice in Education. New York: Routledge.

22)Hargreaves, A. (1994) Changing Teachers, Changing Times: Teachers' Work and Culture in the Postmodern Age. London: Cassell.

23)Hawley, W. and Valli, L. (1999) The Essentials of Effective Professional Development: A New Consensus. In: Darling-Hammond L. and Sykes, G. (Eds.) Teaching as a Learning Profession: Handbook of Policy and Practice (pp.125-152). San Francisco: Jossey-Bass Publishers.

24)Hopkins, D., Ainscow, M. and West, M. (1994) School Improvement in an Era of Change. London: Cassell.

25)Huberman, A.M. and Miles, M.B. (1984) Innovation up Close: How School Improvement Works. New York: Plenum Press.

26)Jelly, M., Fuller, A. and Byers, R. (2000) Involving Pupils in Practice: Promoting Partnerships with Pupils with Special Educational Needs. London: David Fulton.

27)Johnson, D.W. and Johnson, R.T. (1989) Leading the Cooperative School. Edina: Interaction Book Company.

28)Lacey, P. (2003) Effective Multi-agency Work. In: Tilstone, C. and Rose, R. (Eds) Strategies to promote inclusive practice. London: Routledge Falmer.

29)Lambert, L. (2002) The Constructivist Leader. New York: Teachers College Press. 
30)Lawrence, D. (1987) Enhancing Self-esteem in the Classroom. London:Paul Chapman Publishing.

31)Marshall, C. and Olivia, M. (2006) Leaders for social justice: Making revolutions in education. Boston: Allyn and Bacon.

32)Pajak, E. and Evans, K. (2000) Communicative Action: A Postmodern Bridge for Supervision in Schools. In: Glantz, J. and BeharHorestien, L. (Eds) Paradigm Debates in Curriculum and Supervision: Modern and Postmodern Perspective. Pp.229-244. Wesport: Bergin and Garvey.

33)Pij1, S.J., Meijer, C.J.W. and Hegarty, S. (1997) Inclusive Education: A Global Agenda. London: Routledge.

34)Porter, G. (1997) Critical Elements for Inclusive Schools. In: S.J., Pijl, C.J.W., Meijer, and S., Hegarty (Eds) Inclusive education: a global agenda. London: Routledge.

35)Ryan, J. (2003) Leading Diverse Schools. Dordrecht: Kluwer.

36)Ryan, J. (2006a) Inclusive Leadership. San Francisco: Jossey-Bass.

37)Sammons, P., Hillman, J. and Mortimore. P. (1995) Key Characteristics of Effective Schools. London: Institute of Education.

38)Schein, E. (1992) Organisational Culture and Leadership. San Francisco: Jossey-Bass.

39)Sergiovanni, T.J. (1991) The Principalship: A Reflective Practice Perspective. (2nd Ed). Boston: Allyn and Bacon.

40)Sergiovanni, T.J. (1992) Moral Leadership. San Francisco: Jossey Bass Wiley.

41)Sergiovanni, T.J. (1994) Building Community in Schools. San Francisco: Jossey Bass Wiley.

42)Serriere, S. and Mitra, D. (2012) Critical Issues and Contexts of Students Voice in the United State. pp.223-232. In: C., Day (Ed.) The Routledge International Handbook of Teacher and school development. Oxon: Routledge.

43)Smith, R. (1995) Successful School Management. London: Cassell.

44)Stakes, R. and Hornby, G. (2000) Meeting Special Needs in Mainstream Schools: A Practical Guide for Teachers. London: David Fulton.

45)Stoll, L. and Myers, K. (Eds) (1998) No Quick Fixes. Perspectives on Schools in Difficulty. London: Falmer Press.

46)Swaffield, S. and MacBeath, J. ( 2009) Leadership for Learning. In: MacBeath, J. and N. Dempster (Eds) Connecting Leadership and Learning: Principles for Practice. pp. 32-52. London: Routledge.

47)Todd, L. (2007) Partnerships for Inclusive Education: A Critical Approach to Collaborative Working. Oxon: Routledge Falmer.

48)Turnbull, A.P. and Turnbull, H.R. (2001) Families, Professionals, and Exceptionality: Collaborating for Empowerment (4thEd.). Upper Saddle River: Merrill/Prentice-Hall. 
49)Villa, R.A. and Thousand, J.S. (2005) Creating an Inclusive School. Alexandria: Association for Supervision and Curriculum Development.

\section{0)Periodicals and articles}

51)Ainscow, M. and Kaplan, I. (2006) "Using Evidence to Encourage Inclusive School Development: Possibilities and Challenges. Australasian Journal of Special Education. 29 (2). pp.106-116.

52)Alkashrami, S. (2003) "Inclusion of Students with Special Needs in Mainstream Schools', Journal of King Saud University. 16 (1). pp.233-277.

53)Anderson, G. (1990) " Toward a Critical Constructivist Approach to School Administration: Invisibility, Legitimation, and the Study of Nonevents'. Educational Administration Quarterly. 26 (1). pp.38-39.

54)Atta, A., Shah, M. and Khan, M. (2002) “'Inclusive School and Inclusive Teacher'. The Dialogue. IV(2). pp.272-283.

55)Attfield, R. and Williams, C. (2003) "Leadership and Inclusion: A Special School Perspective', British Journal of Special Education. 30 (1). pp.28-33.

56)Avramidis, E. and Norwich, B. (2002): "Teachers' Attitudes towards Integration/ Inclusion: A Review of the Literature'. European Journal of Special Needs Education. 17 (2). pp.129-147.

57)Basu, S.J. (2008) "How Students Design and Enact Physics Lessons: Five Immigrant Caribbean youth and the cultivation of student voice'. Journal of Research in Science Teaching. 45 (8). pp.881-899.

58)Battistich, V. and Horn, A. (1997) “The Relationship between Students' Sense of their School as a Community and their Involvement in Problem Behaviors''. American Journal of Public Health. 87 (12). pp.1997-2001.

59)Billingslley, B., Carlson, E., and Klein, S. (2004) "The Working Conditions and Inclusion Support of early Career Special Educators'. Exceptional Children. 70 (3). pp.333-347.

60)Blase, J. (1990) ' 'Some Negative Effects of Principals' Control Oriented and Protective Behaviour'. American Educational Research Journal. 27 (4). pp.727-753. 
61)Bowers, B. (1990) "Initiating Change in Schools'. National Association of Elementary School Principals. ERIC Document Reproduction Service No. ED 315909.

62)Carrington, S. and Robinson, R. (2004). "A case study of inclusive school development: A journey of learning'. The International Journal of Inclusive Education. 8 (2). pp.141-153.

63)Cole, B.A. (2005) "Mission Impossible? Special Educational Needs, Inclusion and the Re-conceptualization of the Role of the SENCO in England and Wales', European Journal of Special Needs Education. 20 (3). pp.287-307.

64)Davies, J.D. and Lee, J. (2001) 'Learning from Experience or Just Meeting Standards? The Future of Continuing Professional Development Provision for Special Educational Needs Coordinators', Journal of In-Service Education. 27(2). pp.261-274.

65)Day, C., Sammons, P., Hopkins, D., Harris, A., Leithwood, K., Gu, Q., Brown, E., Ahtaridou, E., and Kington, A. (2009) "The Impact of School Leadership on Pupil Outcomes". Research Report RR108. London: DCSF. (978-1-84775-445-5).

66)Deng, M. and Holdsworth, J.C. (2007) "From Unconscious to Conscious inclusion: Meeting Special Education Needs in West China'. Disability and Society. 22 (5). pp.507-522.

67)Epstein, J. (2005) “Attainable Goals? The Spirit and the Letter of the No Child Left Behind Act on Parents', Sociology of Education. 78 (2). pp.179-182.

68)Fan, X. (2001) 'Parental Involvement and Students' Academic Achievement: A Growth Modelling Analysis'. The Journal of Experimental Education. 70 (1). pp.27-61.

69)Foley, R.M. and Lewis, J.A. (1999) "'Self-perceived Competence of Secondary School Principals to Serve as School Leaders in Collaborative-based Educational Delivery Systems', Remedial and Special Education. 20 (4). pp.233-243.

70)Forbes, F. (2007) “Towards Inclusion: An Australian Perspective”. Support for Learning. 22 (2). pp.66-71.

71)Foster, G., Ysseldyke, J.E. and Reese, J.H. (1975) 'II Wouldn't Have Seen it if I Hadn't Believed it’’. Exceptional Children. 41 (7). pp.469-73. 
72)Garcia S.B., Perez A.M. and Ortiz A.A. (2000) "Mexican-American Mothers' Beliefs about Disabilities: Implications for Early Childhood Intervention'. Remedial Special Education. 21 (2). pp.90-102.

73)Guskey, T.R. (2003) "Analyzing Lists of the Characteristics of Effective Professional Development to Promote Visionary Leadership'. National Association of Secondary School Principals (NASSP) Bulletin. 87(637). pp.4-17.

74)Hallinger, P. and Heck, R. (1998) “'Exploring the Principal's Contribution to School Effectiveness: 1980-1995'. School Effectiveness and School Improvement. 9 (2). pp. 157-191.

75)Harris, E. (1992) "A principal and the Evolution of a School Culture: A case study". Planning and Changing. 1 (23). pp.29-44.

76)Hunt, P. and Goetz, L. (1997) "Research on inclusive educational programs, practices, and outcomes for students with severe disabilities". Journal of Special Education. 31 (1). pp.3- 29.

77)Ingram, P.D. (1997) “Leadership Behaviors of Principals in Inclusive Educational Settings', Journal of Educational Administration. 35 (5). pp.411-427.

78)Knoff, H.M. (1984) “Mainstreaming Attitudes and Special Placement Knowledge in Labelling versus Nonlabeling States', Remedial and Special Education. 5 (6). pp.7-14.

79)Kugelmass, J.W. (2001) "Collaboration and Compromise in Creating and Sustaining an Inclusive School'. International Journal of Inclusive Education. 5 (1). pp.47-65.

80)Leo, E. and Barton, L. (2006) "Inclusion, Diversity and Leadership: Perspectives, Possibilities and Contradictions". Educational Management Administration and Leadership: Special Edition Leadership and Diversity. 34 (2). pp.167-180.

81)Lipman, P. (1997) "Restructuring in Context: A Case Study of Teacher Participation and the Dynamics of Ideology, Race and Power'. American Educational Research Journal. 34 (1). pp.3-37.

82)Martin, J., Tett, L. and Kay, H. (1999) "Developing Collaborative Partnerships: Limits and Possibilities for Schools, Parents and Community Education'. International Studies in Sociology of Education. 9 (1). pp.59-75. 
83)McIntosh, R., Vaughn, S., Schumm, J.S., Haager, D., and Lee, O. (1993) "Observations of Students with Learning Disabilities in General Edeucation Classrooms'. Exepctional Children. 60. pp. 249-261.

84)O’Donnell, R.J. and White, G.P. (2005) "Within the Accountability Era: Principals' Instructional Leadership Behaviors and Student Achievement'. National Association of Secondary School Principals (NASSP) Bulletin. 89 (645). pp.56-71.

85)Park, J. and Turnbull, A.P. (2001) “Cross-cultural Competency and Special Education: Perceptions and Experiences of Korean Patents of Children with Special Needs', Education and Training in Mental Retardation and Developmental Disabilities. 36 (2). pp.133-147.

86)Rayner, S., Gunter, H.M. and Powers, S. (2002) "Professional Development Needs for Leaders in Special Education', Journal of In-Service Education. 28 (1), 79-93.

87)Rice, N. (2006) “'Opportunities lost, possibilities found: Shared Leadership and Inclusion in an Urban High School'. Journal of Disability Policy Studies. 17 (2). pp.88-100.

88)Riehl, C.J. (2000) “The Principal's Role in Creating Inclusive Schools for Diverse Students: A Review of Normative, Empirical, and Critical Literature on the Practice of Educational Administration', Review of Educational Research. 70 (1). pp.55-81.

89)Rizzo, T.U. (1984) “Attitudes of Physical Educators Toward Handicapped Pupils”. Adapted Physical Activity Quarterly. 1 (4). pp.267-75.

90)Ryan, J. (2006b) "Inclusive Leadership and Social Justice for Schools". Leadership and Policy in Schools. 5 (1). pp.3-17.

91)Sanzo, K., Clayton, J. and Sherman, W. (2011) "Students with Special Needs, Reading Education, and Principals: Bridging the Divide through Instructional Leadership'. The International Journal of Educational Leadership Preparation. 6 (1). ISSN.2155-9635.

92)Schumm, J.S., and Vaughn, S. (1992) "Planning for Mainstreamed Special Education Students: Perceptions of General Classroom Teachers'. Exceptionality.3 (2). pp. 81-89.

93)Schumm, J.S., and Vaughn, S., Gordon, J. and Rothlein, L. (1994) "General Education Teachers' Beliefs, Skills, and Practices in Planning for Mainstreamed Students with Learning Disabilities'. Teacher Education and Special Education. 17 (1). pp. 22-37 
94)Sheldon, S.B. and Epstein, J.L. (2005) “Involvement Counts: Family and Community Partnerships and Mathematics Achievement', Journal of Educational Research. 98 (4). pp.196-206.

95)Sindelar, P., Shearer, D., Yendol-Hoppey, D. and Liebert, T. (2006) "The Sustainability of Inclusive School Reform'. Council of Exceptional Children. 72 (3). pp.317-331.

96)Sirotnik, K.A. and Kimball, K. (1994) "The Unspecial place of special education in Programs that Prepare School Administrators'. Journal of School Leadership. 4 (5). pp.598-630.

97)Stanovich, P.J. and Jordan, A. (1998). “Canadian teachers' and Principals' Beliefs about Inclusive Education as Predictors of Effective Teaching in Heterogeneous Classrooms', Elementary School Journal. 98 (3). pp.221-238.

98)Theoharis, G. and Causton-Theoharis, J.N. (2008) “Oppressors or emancipators: Critical Dispositions for Preparing Inclusive School Leaders'. Equity and Excellence in Education. 41 (2). pp.230-246.

99)Trainor, A.A. (2010) "Re-examining the Promise of Parent Participation in Special Education: An Analysis of Cultural and Social Capital'. Anthropology and Education Quarterly. 41 (3). pp.245-263.

100)Vaughn, S. and Schumm, J.S. (1995) "Responsible Inclusion for Students with Learning Disabilities', Journal of Learning Disabilities. 28 (5). pp.264-270.

101)Vaughn, S., Schumm, J.S., Jallad, B., Slusher, J. and Saumell, L. (1996) "'Teachers' views of inclusion". Learning Disabilities Research and Practice.11 (2). pp.96-106.

102)Will, M. (1986) "Educating children with learning problems: A shared responsibility'. Exceptional Children. 52 (2). pp.411-416.

103)Zollers, N.J., Ramanathan, A.K. and Yu, M. (1999) “The Relationship between School Culture and Inclusion: How an Inclusive Culture Supports Inclusive Education', International Journal of Qualitative Studies in Education. 12 (2). pp.157-174.

104)Miscellaneous

DOI $10.12816 / 0052741$ 
105)Ainscow, M. (2001) Developing Inclusive Schools: implications for leadership. Paper prepared for the National College for School Leadership. Online. Avilable from: http://www.nationalcollege.org.uk .Accessed at: 14/1/ 2012.

106)Ainscow, M. (2005) The Next Big Challenge: Inclusive School Improvement. Akeynote address to the International Congress for School Effectiveness and Improvement, Barcelona. Spain, January.

107)Alabdaljabbar, A. and Massoud, W. (2001) Investigation of the Views of Managers and Teachers in Regular Schools on Integration programs. Educational Research Centre. Riyadh: King Saud University.

108)Dyson, A., Gallannaugh, F., and Millward, A. (2002) 'Making Space in the Standards Agenda: Developing Inclusive Practices in Schools'. Paper presented at the European Conference on Educational Research. Lisbon:Portugal.

109)McRel (Mid-continent Research for Education and Learning)(2000) Asking the Right Questions. Aurora, CO: Mid-Continent Regional Education Lab.

110)McLaughlin, M.J. and Warren, S.H. (1993) "Do Inclusion Practices Cost More? Impressions of Special Education at Eleven Site', Palo Alto: Centre for Special Education Finance.

111)Sartawi, Z., Sartawi, A. and Jalal, J. (1988) Identifying the Views of Teachers and Managers in the City of Riyadh on the Patterns of Appropriate Educational Service for Disabled Students and Integration. Centre for Educational Research. Riyadh: King Saud University. 
